\title{
Is Enhanced Audit Quality Associated with Greater Real Earnings Management?
}

\author{
Wuchun Chi \\ National Chengchi University \\ Department of Accounting \\ Taipei, Taiwan \\ wchi@nccu.edu.tw \\ Ling Lei Lisic* \\ George Mason University \\ School of Management \\ Fairfax, VA 22030 \\ $\underline{\text { llei1@gmu.edu }}$ \\ Mikhail Pevzner \\ George Mason University \\ School of Management \\ Fairfax, VA 22030 \\ mpevzner@gmu.edu
}

November 2010

\footnotetext{
${ }^{*}$ Corresponding author. We thank Dana Hermanson (the Editor), two anonymous reviewers, and the workshop participants at George Mason University and Peking University for their helpful comments and suggestions. Chi acknowledges the financial support from National Science Council and Pevzner acknowledges summer research grants from George Mason University's Provost and Accounting Advisory Council. All errors are our own.
} 


\title{
Is Enhanced Audit Quality Associated with Greater Real Earnings Management?
}

\begin{abstract}
We examine whether firms resort to real earnings management when their ability to manage accruals is constrained by higher quality auditors. In settings involving strong upward earnings management incentives, i.e., for firms that meet or just beat earnings benchmarks and firms that issue seasoned equities, we find that city-level auditor industry expertise and audit fees are associated with higher levels of real earnings management. We find similar, albeit weaker, results for the Big $\mathrm{N}$ auditors. Our paper suggests an unintended consequence of higher quality auditors constraining accrual earnings management, namely, firms resorting to potentially even more costly real earnings management. We also find that longer auditor tenure is associated with greater real earnings management, which could suggest merits of mandating audit firm rotation.
\end{abstract}

Keywords: real earnings management, audit quality, industry expertise, auditor tenure, audit fees.

JEL classifications: M40, M41 


\section{Introduction}

In this paper, we examine the association between audit quality and real earnings management.

Prior literature suggests that higher quality auditors reduce the level of accrual earnings

management (Becker et al. 1998; Johnson et al, 2002; Balsam et al. 2003). We argue that, as a consequence of constrained accrual earnings management, clients of higher quality auditors likely resort to more real activities manipulation. Thus, we expect that higher audit quality is associated with higher levels of real earnings management when firms have strong incentives to manage earnings.

Prior research suggests that accruals and real activities are two alternative ways to manage earnings (Roychowdhury 2006; Cohen et al. 2008; Zang 2007). While earlier studies focus on accrual earnings management (Jones 1991; Teoh et al. 1998), more recent papers suggest that firms also engage in real earnings management (Roychowdhury 2006; Kim et al. 2010; Cohen and Zarowin 2010). Real earnings management potentially imposes greater longterm costs on shareholders than accrual earnings management because it has negative consequences on future cash flows and might hurt firm value in the long run (Roychowdhury 2006; Cohen et al. 2008; Cohen and Zarowin 2010). Such long term costs are driven by temporary price discounts or more lenient credit terms that lower margins on future sales, reductions in valuable investments in research and development and SG\&A activities, and/or 
increasing investments in un-needed inventories via inventory over-production (Roychowdhury 2006; Gupta et al. 2010). Cohen and Zarowin (2009) also find evidence that firms engaging in real earnings management over-invest, which could adversely affect firms' long-term prospects.

However, managing real activities is less costly to managers because it is less likely to draw auditor or regulatory scrutiny (Cohen et al. 2008). Real earnings management, as long as it is properly disclosed in the financial statements, cannot influence auditors' opinions or regulators' actions (Gupta et al. 2010). Hence, managers could prefer real earnings management to accrual earnings management (Roychowdhury 2006).

Zang (2007) documents that accrual earnings management and real earnings management function as substitutes. Thus, we expect that firms are more likely to engage in more extensive real earnings management when their ability to manage accruals is constrained. We can also derive this prediction from the theoretical work of Ewert and Wagenhofer (2005), whose model shows that firms resort to real earnings management when their accounting flexibility is reduced. One way to reduce a firm's accounting flexibility is to engage an auditor who is less agreeable to earnings management. ${ }^{1}$ Prior research shows that higher quality auditors are more successful in constraining accrual earnings management, i.e. they constrain accounting flexibility of managers.

\footnotetext{
${ }^{1}$ Other possible ways are introductions of less flexible accounting standards or more stringent governance mechanisms.
} 
Consequently, higher audit quality could be associated with higher levels of real earnings management among firms with incentives to manage earnings.

Recent work by Reichelt and Wang (2010) shows that auditor industry specialization is a critical indicator of audit quality. In particular, clients of such auditors have lower discretionary accruals and are less likely to just meet analyst expectations. Other studies also find that industry expert auditors are associated with lower likelihood of being involved in SEC enforcement actions (Carcello and Nagy 2004) and lower probabilities of restatements (Romanus et al. 2008). Prior research also suggests that audit firm size (Big N vs. non-Big N) is another indicator of audit quality. Studies find that the Big N auditors charge higher audit fees (Craswell et al. 1995), and they are associated with lower absolute value of discretionary accruals (Becker et al. 1998) and higher ERCs (Teoh and Wong 1993). Thus, we focus on these two auditor characteristics, namely, auditor industry expertise and audit firm size, and examine their association with levels of real earnings management.

Following Reichelt and Wang (2010), we measure auditor industry expertise as the audit fee market share of each auditor in each industry at both the national level and the city-level. We measure audit firm size as a Big N. vs. non-Big N indicator. Following Roychowdhury (2006) and Cohen et al. (2008), our proxies for real earnings management are estimates of a firm's 
abnormal cash flows, abnormal inventory production, abnormal discretionary expenditures, and a summary measure combining these three components.

We focus on a sample of 925 firm-year observations from 2001 to 2008 that likely have strong incentives to manage earnings upwards (identified ex post or ex ante), i.e., firms that meet/just beat one of the earnings benchmarks (zero earnings, previous year's earnings, and analyst forecasts) and firms that issue seasoned equity offerings. Our primary finding is that within that sample city-level auditor industry expertise is associated with higher levels of the overall real earnings management index and each of the components of the real earnings management index, i.e., lower levels of abnormal cash flows, higher levels of abnormal production, and lower levels of abnormal discretionary expenditures. We also find that the Big $\mathrm{N}$ auditors are associated with higher overall levels of the real earnings management index and lower levels of abnormal cash flows. When we use audit fees as an alternative measure of audit quality in additional analyses, we find similar results, i.e., higher audit fees are associated higher levels of real earnings management. Collectively, our findings are consistent with our prediction that higher audit quality is associated with higher levels of real earnings management for firms that have strong incentives to manage earnings. In addition, we find that longer auditor tenure is associated with higher levels of real earnings management at both the overall level and the 
individual component level among firms with incentives to manage earnings. ${ }^{2}$ Finally, we find that the positive association between city-level industry expertise and real earnings management measures is significantly stronger in the upward earnings management sample than in the sample lacking of such incentives (i.e., all sample excluding the upward earnings management sample).

Our paper contributes to the literature by demonstrating that firms adapt to the presence of more stringent levels of auditing by engaging in real earnings management. Past auditing research has exclusively focused on accrual earnings management when examining the impact of audit quality on the clients' behavior. Our paper suggests that an unintended consequence of higher quality auditors constraining accrual earnings management is that clients resort to higher levels of real earnings management, which is potentially more costly to the shareholders in the long run. Furthermore, our findings regarding the positive association between auditor tenure and real earnings management shed additional insights into the long and heated debate of whether

\footnotetext{
${ }^{2}$ Our results complement Cohen and Zarowin (2010), which examine firms that issue seasoned equities only and in one of the tests find that the Big 8 auditors and auditor tenure are associated with the probability of clients' overall levels of real earnings management index being above the sample median. However, we note that Cohen and Zarowin (2010) do not consider the impact of auditor industry expertise, which according to the results in Reichelt and Wang (2010) is a dominant audit quality measure. In addition, our paper considers a broader set of incentives for real earnings management, including but not limited to seasoned equity offerings. Finally, we study individual components of real earnings management, in addition to the composite index studied in Cohen and Zarowin (2010). In addition, a contemporaneous study, Yu (2008), examines national level auditor industry expertise only and finds a positive relation with real earnings management. We take a broader view and use multiple proxies for audit quality. We find that city-, but not national, level industry expertise is associated with greater real earnings management.
} 
audit firm rotation should be mandated (AICPA 1978, 1992; SOX 2002; GAO 2003; Cox 2006).

Past research has exclusively focused on accrual earnings management when analyzing the benefits/costs of mandatory auditor rotation (Johnson et al. 2002; Myers et al. 2003; Davis et al. 2009). Our results alert regulators and researchers that mandating audit firm rotation could potentially reduce real earnings management, a benefit that has not been documented in prior research.

Our paper proceeds as follows. Section 2 reviews the literature and develops our hypotheses. Section 3 discusses research design. Section 4 describes our sample. Section 5 presents empirical results. Section 6 contains additional analyses. Finally, Section 7 concludes.

\section{Literature Review and Hypothesis Development}

Prior research suggests that firms manage both accruals and real activities to maximize their valuations, avoid negative contracting consequences such as violations of debt covenants, and/or avoid negative regulatory consequences. While earlier papers focus more on accrual management (e.g., Jones 1991; Teoh et al. 1998), more recent papers suggest real activities manipulation for objectives similar to accrual earnings management. In particular, Roychowdhury (2006) finds that firms manage real activities to avoid missing earnings targets. Cohen and Zarowin (2010) report that firms engage in real earnings management in the year of 
seasoned securities offerings (SEO) to avoid SEO under-pricing. Kim et al. (2010) find that firms engage in greater real activities manipulation when they are closer to debt covenant violations.

The departing assumption of our paper is that, among firms with incentives to manage earnings, accruals and real earnings management are substitutes. When costs of accrual earnings management are higher, ceteris paribus, firms are more likely to engage in real earnings management. In particular, Zang (2007) and Cohen et al. (2008) suggest that the presence of more stringent litigation and regulatory regime drives firms to real earnings management. This happens because real earnings management does not involve direct violation of any laws or regulations, as long as the outcomes of real earnings management are properly disclosed in the financial statements. This reasoning suggests that firms might switch from accrual earnings management to real earnings management when opportunities of accrual earnings management are constrained. Consistent with this argument, Ewert and Wagenhofer (2005) show analytically that when accounting standards are tightened, i.e. when accounting flexibility is reduced, firms tend to resort to real earnings management. Cohen et al. (2008) provide initial empirical support to Ewert and Wagenhofer's model. SOX has imposed greater regulatory scrutiny on firms and, potentially, reduced their accounting flexibility. Cohen et al. (2008) find that, consequently, firms engage in less accrual earnings management, but more real earnings management postSOX. An alternative way to reduce accounting flexibility is to engage an auditor less agreeable 
to accrual earnings management. Hence, we examine whether firms, conditional on incentives to manage earnings, resort to real earnings management when their auditors are of higher quality.

We focus on two auditor characteristics that proxy for higher level of audit quality: auditor industry expertise and audit firm size. A wide literature suggests that auditor industry expertise enhances audit quality and thus credibility of financial reporting. Craswell et al. (1995) find that audit specialists command higher fees. Knechel et al. (2007) find that firms audited by specialists receive higher valuations, and Dunn and Mayhew (2004) find that these firms have better disclosure quality. Balsam et al. (2003) and Krishnan (2003) find that auditor industry expertise is associated with lower levels of accrual earnings management. In addition to lower accruals, Reichelt and Wang (2010) show that auditor industry specialization is associated with lower likelihood of clients just meeting analyst expectations. Griffin et al. (2009) suggest that industry expert auditors have a greater propensity to issue going concern opinions. Carcello and Nagy (2004) find that industry expert auditors are less likely to be involved in SEC enforcement actions. Romanus et al. (2008) find clients of industry expert auditors have lower probabilities of restatements.

The literature also recognizes that the Big $\mathrm{N}$ auditors provide higher quality audits and offer greater credibility to clients' financial statements than the non-Big $\mathrm{N}$ auditors. Nichols and Smith (1983) find that the stock market reacts more favorably when a client switches to a Big N 
auditor than when it switches to a non-Big N auditor. Lennox (1999) suggests that the Big $\mathrm{N}$ auditors give more accurate signals of financial distress in their audit opinions. Craswell et al. (1995) document that the Big $\mathrm{N}$ auditors charge an audit fee premium over the non-Big $\mathrm{N}$ auditors. Studies also show that clients of the Big $\mathrm{N}$ auditors have lower absolute values of discretionary accruals (Becker et al. 1998) and higher ERCs (Teoh and Wong 1993). Firth and Smith (1992) find that clients of the Big N auditors incur less IPO underpricing than clients of the non-Big $\mathrm{N}$ auditors.

Thus, based on prior findings that industry expert auditors and the Big $\mathrm{N}$ auditors constrain their clients' ability to manage earnings via accruals, we expect that their clients will resort to more real earnings management given incentives to manage earnings. Hence, our prediction is:

Hypothesis: Audit quality, as operationalized by auditor industry expertise and the presence of a Big $N$ audit firm, is associated with higher levels of real earnings management among firms with incentives to manage earnings.

\section{Research Design}


We focus on contexts in which the literature has shown that firms have strong incentives to manage earnings upwards. We identify these firms ex post as firms that meet or just beat earnings benchmarks (zero earnings, previous year's earnings, and analyst forecasts) and ex ante as firms that issue seasoned equity offerings. Following Roychowdhury (2006), we define firms as meeting or just beating zero earnings benchmarks if their net income scaled by total assets at the beginning of the year falls into the interval $[0,0.005]$. We similarly define firms as meeting or just beating previous year's earnings benchmarks if their change in net income scaled by total assets at the beginning of the year falls into the interval between $[0,0.005] .{ }^{3}$ Finally, we define firms as meeting or just beating analyst forecasts if their actual annual EPS figures reported by I/B/E/S are larger than the most recent consensus analyst forecasts before earnings announcements by 1 cent or less (Roychowdhury 2006). Following Gupta et al. (2010), we define firms as issuing seasoned equity offerings if Compustat reports a non-zero data item SSTK. ${ }^{4}$ To maximize the sample size, we pool all firms that satisfy at least one of the four conditions for upward earnings management, i.e., firms meeting or just beating one of the three earnings benchmarks or issuing seasoned equity offerings.

\footnotetext{
${ }^{3}$ Widening the intervals for defining firms as meeting or just beating zero earnings and previous year's earnings benchmarks to $[0,0.01]$ or $[0,0.02]$ generates very similar results.

${ }^{4}$ Following Cohen and Zarowin (2010) and Gupta et al. (2010), we measure seasoned equity offerings in year $t$, i.e., in the same year as our real earnings management measures. Our results are robust to measuring seasoned equity offering in year $t+l$ to examine real earnings management in anticipation of seasoned equity offerings.
} 
We follow Roychowdhury (2006) and Cohen et al. (2008) in defining our proxies for real earnings management. As in these two papers, we consider abnormally low levels of cash flow from operations and discretionary expenses, and abnormally high levels of production costs as indicators of upward real activities manipulations. Our estimations of abnormal cash flow $\left(A b n \_C F O\right)$, abnormal production costs (Abn_Prod) and abnormal discretionary expenses (Abn_Discexp) follow Cohen et al. (2008). Specifically we calculate Abn_CFO as residuals of regression model (A), which is estimated by year and industry identified using two-digit SIC code:

$\mathrm{CFO}_{\mathrm{it}} /$ Assets $_{\mathrm{i}, \mathrm{t}-1}=\mathrm{a}_{1 \mathrm{t}}\left(\right.$ (1/Assets $\left._{\mathrm{i}, \mathrm{t}-1}\right)+\mathrm{a}_{2 \mathrm{t}}\left(\right.$ Sales $_{\mathrm{i}, \mathrm{t}} /$ Assets $\left._{\mathrm{i}, \mathrm{t}-1}\right)+\mathrm{a}_{3 \mathrm{t}}\left(\Delta\right.$ Sales $_{\mathrm{i}, \mathrm{t}} /$ Assets $\left._{\mathrm{i}, \mathrm{t}-1}\right)+\varepsilon_{\mathrm{it}}(\mathrm{A})$ where $C F O$ is cash flow from operations.

We similarly calculate Abn_Prod as residuals of regression model (B):

$\operatorname{Prod}_{i t} /_{\text {Assets }_{i, t-1}}=b_{1 t}\left(1 /\right.$ Assets $\left._{i, t-1}\right)+b_{2 t}\left(\operatorname{Sales}_{i, t} / \operatorname{Assets}_{i, t-1}\right)+b_{3 t}\left(\Delta \operatorname{Sales}_{i, t} /\right.$ Assets $\left._{i, t-1}\right)$

$$
+\mathrm{b}_{4 \mathrm{t}}\left(\Delta \text { Sales }_{\mathrm{i}, \mathrm{t}-1} / \text { Assets }_{\mathrm{i}, \mathrm{t}-1}\right)+\mathrm{e}_{\mathrm{it}}
$$

where Prod is sum of cost of goods sold and change in inventory in year t.

Finally, we calculate Abn_Discexp as residuals of regression model (C):

$\operatorname{Discexp}_{i t} /$ Assets $_{i, t-1}=c_{1 t}\left(1 /\right.$ Assets $\left._{i, t-1}\right)+c_{2 t}\left(\right.$ Sales $_{i, t-1} /$ Assets $\left._{i, t-1}\right)+v_{i t}$

where Discexp is the sum of advertising expenses, R\&D expenses, and SG\&A expenses. 
Also, following Cohen et al. (2008), we develop a comprehensive measure of real earnings management by combing the three individual measures. Specifically, we compute REM_Index as the sum of the three standardized individual components, i.e., - standardized $A b n \_C F O+$ standardized Abn_Prod - standardized Abn_Discexp. Higher levels of REM_Index indicate higher levels of overall real earnings management. Because the three individual variables provide richer information regarding real earnings management than using REM_Index alone, we report results corresponding to the comprehensive real earnings management index (REM_Index) as well as the three individual real earnings management proxies ( $A b n \_C F O$, Abn_Prod, and Abn_Discexp).

To test our hypotheses, we extend the models in Cohen et al. (2008) by including proxies for auditor industry expertise and an indicator variable for the Big $\mathrm{N}$ auditors. Earlier studies measure industry expertise at the national level and find that national level industry experts charge higher audit fees and are associated with lower abnormal accruals (Craswell et al. 1995; Balsam et al. 2003). However, more recent studies (Ferguson et al. 2003; Francis et al. 2005; Reichelt and Wang 2010) argue that industry expertise should be measured locally at the citylevel because industry expertise derives from deep client knowledge of professionals working in local audit offices, which is not easily transferable nation-wide. Consistent with this, Ferguson et al. (2003) and Francis et al. (2005) both find that national level industry experts do not earn an 
audit fee premium when they are not city-level industry experts; however, city-level industry experts can charge an audit fee premium when they are not national level industry experts.

Similarly, Reichelt and Wang (2010) find that auditors that are designated as industry experts at the city-level but not at the national level are associated with lower abnormal accruals, but not vice versa. These studies suggest that city-level industry expertise dominates national level industry expertise. Thus, we follow Reichelt and Wang (2010) and measure industry expertise at both city- and national level and capture industry expertise as the auditor's audit fee market share in each two-digit SIC code industry.

Thus, to test our hypothesis, we run the following regression model for the sample of firms that we identify as having strong incentives to manage earnings upwards, i.e., firms that meet or just beat one of the three earnings benchmarks (zero earnings, previous year's earnings, and analyst forecasts) or issue seasoned equity offerings: ${ }^{5}$

\footnotetext{
${ }^{5}$ An alternative way to test our hypothesis is to use the full sample regardless of earnings management incentives and generate a dummy variable Incentive $=1$ if firms meet or just beat earnings benchmarks or issue seasoned equity offerings, and 0 otherwise. Then, we can run the following regression model:

REM $_{t}=a_{0}+a_{1} *$ Incentive $_{t}+a_{2}$ IndExp_city ${ }_{t}+a_{3}$ IndExp_national ${ }_{t}+a_{4}$ BigN $_{t}+a_{5}$ Tenure $_{t}+a_{6}$ Incentive $^{*}$ IndExp_city $+a_{7}$ Incentive $*$ IndExp_national $_{t}+a_{8}$ Incentive $^{*}$ BigN $_{t}+a_{9}$ Incentive $^{*}$ Tenure $_{t}+a_{10} *$ Lev $_{t-1}+a_{11} * L_{M V} E_{t-1}+a_{12} * M T B_{t-1}$ $+a_{13} * \Delta E_{t-1}+a_{14} * R_{\text {ROA }}+1+a_{15} *$ ExOption $_{t}+a_{16} *$ UnOption $_{t}+a_{17} *$ Owner $_{t}+a_{18} *$ Bonus $_{t}+a_{19} *$ Year Dummies $+e_{t}$ We can test the signs of the coefficients on the interaction terms (i.e., Incentive*IndExp_city, Incentive*IndExp_national, and Incentive*BigN) to test our hypothesis. We do not choose this research design because there appear to be multicollinearity problems in the regression models. The collinearity condition index is 37 and the highest variance inflation factor is 43 (the rule of thumb is that collinearity condition index larger than 30 and/or variance inflation factor larger than 10 indicates multicollinearity).
} 


$$
\begin{aligned}
\text { REM }_{t}= & a_{0}+a_{1} * \text { IndExp_city }_{t}+a_{2} * \text { IndExp_national }_{t}+a_{3} * \text { BigN }_{t}+a_{4} * \text { Tenure }_{t}+a_{5} * \text { Lev }_{t-1}+a_{6} * \text { LMVE }_{t-1} \\
& +a_{7} * \text { MTB }_{t-1}+a_{8} * \Delta E_{t-1}+a_{9} * R O A_{t-1}+a_{10} * \text { ExOption }_{t}+a_{11} * \text { UnOption }_{t}+a_{12} * \text { Owner }_{t} \\
& +a_{13} * \text { Bonus }_{t}+a_{14} * \text { Year Dummies }+e_{t}
\end{aligned}
$$

where the variables are defined as follows:

REM = Real earnings management variables defined based on Cohen et al. (2008):

Abn_CFO: Abnormal cash flows (negative measure of real earnings management)

Abn_Prod: Abnormal inventory over-production (positive measure of real earnings management)

Abn_Discexp: Abnormal discretionary expenses (negative measure of real earnings management)

REM_Index: - standardized Abn_CFO + standardized Abn_Prod standardized Abn_Discexp (positive composite score of real earnings management). Standardized measure for each variable $=$ [variable - mean(variable)] / standard deviation(variable)

IndExp_city $\quad=$ Audit fee market share of the local office of auditor in the city-industry combination

IndExp_national $=$ Audit fee market share of the auditor in the industry

BigN $\quad=\quad 1$ if auditor is a Big $\mathrm{N}$ audit firm, and 0 otherwise

Tenure $\quad=$ Number of years the auditor has audited the company's financial statements

LMVE $\quad=\quad$ Natural log of market value of equity for a firm

$M T B \quad=$ A firm's market-to-book ratio

$\triangle E$

$=$ Change in a firm's annual earnings, deflated by prior year assets

ROA $=\mathrm{A}$ firm's return on assets defined as the ratio of earnings before extraordinary items deflated by prior period assets

ExOption $\quad=$ Value of executive exercisable (i.e., vested) options at the end of the year from Execucomp

UnOption $\quad=\quad$ Value of executive un-exercisable (i.e., un-vested) options at the end of the year from Execucomp

Owner = The sum of restricted stock grants in the current period and the aggregate number of shares held by the executive at year-end (excluding stock options) scaled by total outstanding shares of the firm, computed using Execucomp data

Bonus $\quad=$ Average bonus compensation as a proportion of total compensation received by the $\mathrm{CEO}$ and the $\mathrm{CFO}$ of the firm from Execucomp. 
If auditor industry expertise constrains accrual earnings management and consequently clients resort to real earnings management, we would expect the coefficient on IndExp_city to be positive when we use REM_Index as the dependent variable. When we use each of the three components of REM_Index, i.e., Abn_CFO,Abn_Prod and Abn_Discexp, as the dependent variable, we expect the coefficients on IndExp_city to be negative, positive, and negative, respectively. Since we expect that industry expertise at city-level dominates industry expertise at national level, we expect that the corresponding coefficients on IndExp_national will be insignificant. Similarly, if Big $\mathrm{N}$ auditors constrain accrual earnings management and consequently clients resort to real earnings management, we expect the coefficient on $B i g N$ to be positive when we use REM_Index as the dependent variable. When we use each of its three components, Abn_CFO,Abn_Prod and Abn_Discexp, as the dependent variable, we expect the coefficients on BigN to be negative, positive, and negative, respectively. Since studies (e.g., Reichelt and Wang 2010) have shown that auditor industry specialization could subsume the effects of the Big $\mathrm{N}$ when both are included in the same regression model, our results on BigN could be weaker than on IndExp_city. ${ }^{6}$

\footnotetext{
${ }^{6}$ In Table 7 of Reichelt and Wang (2010), where they report the Logit regression results of meeting or beating analyst earnings forecasts, their city-level industry expertise variables are all significantly negative in all specifications. In contrast, the Big 4 indicator variable is always insignificant.
} 
We control for audit firm tenure (Tenure) in the regression. There is considerable debate in the literature regarding whether longer auditor tenure is associated with higher or lower audit quality. On the one hand, longer auditor tenure familiarizes auditors with clients' operations and therefore helps auditors perform better auditors. On the other hand, longer auditor tenure could lead to more friendly relationships with the management and therefore might impair auditor independence. Empirical evidence on whether longer or shorter auditor tenure indicates higher audit quality is also mixed. Johnson et al. (2002) and Myers et al. (2003) both show that longer auditor tenure is associated with lower discretionary accruals. However, Davis et al. (2009) find that, pre-SOX, longer audit firm tenure is associated with deteriorating audit quality in the form of a client's ability to use discretionary accruals to meet or beat forecasts. They do not find an association between tenure and discretionary accruals post-SOX. If longer (shorter) auditor tenure indicates higher audit quality, auditors with longer (shorter) tenure would constrain accrual earnings management to a greater extent and consequently clients would resort to more real earnings management. Thus, we would expect the coefficient on Tenure to be positive (negative) when we use REM_Index as the dependent variables. In this case, when we use each of its three components, Abn_CFO,Abn_Prod and Abn_Discexp, as the dependent variable, we expect the coefficient on Tenure to be negative (positive), positive (negative), and negative (positive), respectively. 
We argue that it is important to investigate the association between auditor tenure and real earnings management because the finding will shed additional light onto the long and heated debate of whether audit firm rotation should be mandated (AICPA 1978, 1992; Cox 2006). The Sarbanes-Oxley Act (SOX) even required the General Accounting Office (GAO) to conduct a study of the potential effects of mandating audit firm rotation. Prior empirical research exclusively focuses on accrual earnings management when performing the cost-benefit analysis of longer auditor tenure. We argue that real earnings management should be an important part of the cost-benefit analysis as well and that has been missing in prior research.

We also control for other variables adapted from Cohen et al. (2008) and for fixed-year effects. To mitigate the influence of potential outliers, we winsorize all continuous variables at their respective $1^{\text {st }}$ and $99^{\text {th }}$ percentiles. Following Gow et al. (2010), we report test statistics based on the two-way cluster-robust standard errors (cluster by firm and by year) which adjust for both cross-sectional and time-series dependence in panel data.

\section{Sample Selection and Data Descriptions}

We calculate city-level and national level auditor industry expertise using audit fee data

from Audit Analytics. Since audit fee disclosures were first mandated in 2001, our sample ranges from 2001 to 2008. There are 104,588 such firm-year observations. Requiring Compustat 
coverage for non-financial and non-utilities firms results in a loss of 38,473 observations. Following Roychowdhury (2006), we require at least 15 observations in each industry-year group with available data for regression models (A)-(C) to calculate real earnings management measures (Abn_CFO,Abn_Prod, and Abn_Discexp). Such data requirements reduce the sample by 40,882 observations. Requiring availability of the additional Compustat control variables (e.g., auditor tenure, leverage, firm size, earnings level and change, and market-to-book ratio) reduces our sample size to by another 9,206 observations. We then merge with the Execucomp database to calculate executive compensation variables as our control variables (i.e., executive option holdings, bonus, and ownership), which reduces our sample size by 12,123 observations, resulting in 3,904 observations. Finally, because we focus only on firms that have strong incentives to manage earnings upwards, i.e., firms that meet or just beat earnings benchmarks (zero earnings, previous year's earnings, and analyst forecasts) and firms that issue seasoned equities, we drop 2,979 firm-year observations. Our final sample consists of 925 firm-year observations. Table 1 presents the sample selection procedures.

Panels A-C of Table 2 provide descriptive statistics for the estimated coefficients and $\mathrm{R}^{2} \mathrm{~S}$ from the industry-year regression results that estimate the components of real earnings management (i.e., Abn_CFO,Abn_Prod, and Abn_Discexp). These regressions are based on all observations in Compustat with available data for Models (A)-(C) before we implement 
additional data requirements for Model (1). There are 337 such industry-year groups from 2001 to 2008. Our statistics are similar to those reported in Roychowdhury (2006).

Panel D of Table 2 provides descriptive statistics for all variables in our regression models. The mean REM_Index is -0.230 . The means of its three components, Abn_CFO, Abn_Prod, and Abn_Discexp, are 0.055, -0.048 , and 0.026, respectively, consistent with those reported in Cohen et al. (2008). On average, auditor's city-level industry market share (IndExp_city) is 0.488 , suggesting that a local audit office on average holds 48.8 percent of the audit fee market share in a city-industry combination. In comparison, the mean national level industry market share of the auditor (IndExp_national) is smaller at 0.245 , suggesting that an audit firm on average holds 24.5 percent of the national audit fee market share in an industry. Finally, 96.8 percent of our sample is audited by the Big $\mathrm{N}$ accounting firms, and the mean of auditor tenure (Tenure) is 12.872 years.

Table 3 represents the pairwise Pearson and Spearman correlations. By construction, Abn_CFO,Abn_Prod, and Abn_Discexp are negatively, positively, and negatively correlated with $R E M \_I n d e x$, respectively. IndExp_city is positively correlated with REM_Index, positively correlated with Abn_Prod, and negatively correlated with Abn_discexp. The Pearson correlation between BigN and REM_Index is positive. Tenure is positively correlated with REM_Index, negatively correlated with $A b n \_C F O$, positively correlated with $A b n \_P r o d$, and negatively 
correlated with Abn_Discexp. These correlations suggest that, overall, auditor industry expertise and tenure are correlated with greater levels of real earnings management. The correlation between Big $\mathrm{N}$ auditors and real earnings management is weaker. However, we acknowledge that all these are merely univariate associations and we should rely on the multiple regression analyses for our inferences.

\section{Empirical Findings}

We first confirm using our sample the results found in the literature regarding the negative association between audit quality and accrual earnings management. We run the following regression model (2) extending Cohen et al. (2008):

$$
\begin{aligned}
D A_{t}= & a_{0}+a_{1} * \text {IIndExp_city }_{t}+a_{2} * \text { IndExp_national }_{t}+a_{3} * \text { BigN }_{t}+a_{4} * \text { Tenure }_{t}+a_{5} * \text { Lev }_{t-1} \\
& +a_{6} * \text { LMVE }_{t-1}+a_{7} * \text { MTB }_{t-1}+a_{8} * \text { UE }_{t-1}+a_{9} * \text { ROA }_{t-1}+a_{10} * \text { ExOption }_{t}+a_{11} * \text { UnOption }_{t} \\
& +a_{12} * \text { Owner }_{t}+a_{13} * \text { Bonus }_{t}+a_{14} * \text { Year Dummies }+e_{t}
\end{aligned}
$$

where

$D A_{t}=$ modified Jones (1991) model of discretionary accruals with control for contemporaneous accounting performance as suggested in Kothari et al (2005)

All other variables are as defined before. We expect negative coefficients on IndExp_city and BigN. If city-level industry expertise dominates national level industry expertise, we would 
not find the coefficient on IndExp_national to be significant. If longer (shorter) auditor tenure indicators higher audit quality by constraining accrual earnings management, we expect the coefficient on Tenure to be negative (positive). We report our findings in Table 4. Consistent with our expectations, we find a negative coefficient of $-0.020(t=-3.30)$ on IndExp_City, an insignificant coefficient of -0.014 (t=-0.67) on IndExp_national, and a negative coefficient of $-0.019(t=-1.65)$ on $B i g N$. Our results are consistent with the literature, suggesting that city-level auditor industry expertise and the Big $\mathrm{N}$ auditors constrain accrual management. We also find a negative coefficient of $-0.001(t=-4.63)$ on Tenure, suggesting that longer auditor tenure is associated with lower accrual earnings management for our sample.

Table 5 presents our main results. ${ }^{7}$ We find a positive coefficient of 0.947 ( $\left.t=3.54\right)$ on IndExp_city in the REM_Index regression, suggesting that city-level auditor industry expertise is associated with more overall real activity earnings management. We also present regression results in the next three columns using each of the three components of REM_Index as dependent variables. Consistent with the REM_Index results, we find a negative coefficient of -0.040 ( $t=-$ 3.02), a positive coefficient of $0.119(t=3.12)$, and a negative coefficient of -0.113 ( $t=-3.09)$ on IndExp_city in the Abn_CFO, Abn_Prod, and Abn_Discexp regressions, respectively. These

\footnotetext{
${ }^{7}$ Our results are robust to adding $D A$ as a control variable.
} 
results suggest that higher city-level auditor industry expertise is associated with lower abnormal cash flow, higher abnormal production, and lower discretionary expenses. Collectively, these results suggest that higher city-level auditor industry expertise is associated with more real earnings management, an unintended consequence of higher city-level auditor industry expertise constraining accrual earnings management. In all four regressions, we fail to find significant coefficients on IndExp_national, suggesting that higher national level auditor industry expertise is not associated with more real earnings management. This result is consistent with the findings in prior studies (Ferguson et al. 2003, Francis et al. 2005, Reichelt and Wang 2010) that industry expertise should be measured at the city-level, not at the national level.

Furthermore, we find a positive coefficient of 0.509 ( $t=1.85)$ on BigN in the REM_Index regression, suggesting that the Big $\mathrm{N}$ auditors are associated with more overall real earnings management. Consistent with the REM_Index results, we find a negative coefficient of -0.041 ( $t=-1.82)$ on $B i g N$ in the $A b n_{-} C F O$ regression, suggesting that the Big $\mathrm{N}$ auditors are associated with lower abnormal cash flows. Although the coefficients on BigN in the Abn_Prod and Abn_ Discexp regressions are insignificant at conventional levels, their signs are consistent with our predictions. Our results on BigN are weaker than on IndExp_city; however, this is consistent with the evidence in Reichelt and Wang (2010) that the city-level industry expertise effect dominates the Big $\mathrm{N}$ effect for firms that meet or just beat earnings benchmarks. In addition, Panel $\mathrm{D}$ of 
Table 2 shows that 96.8 percent of our sample is audited by the Big $\mathrm{N}$ accounting firms. The lack of variation could also explain our weaker results on the Big $\mathrm{N}$ indicator variable. Collectively, these results provide some evidence that the Big $\mathrm{N}$ auditors are associated with more real earnings management, an unintended consequence of the Big $\mathrm{N}$ auditors constraining accrual earnings management.

Although empirical evidence on the association between auditor tenure and accrual earnings management is mixed, we find that longer auditor tenure is associated higher levels of real earnings management at both the overall level and the individual component level. Specifically, we find a positive coefficient of $0.019(t=2.46)$, a negative coefficient of $-0.001(t=$ -2.58), a positive coefficient of $0.002(t=2.42)$, and a negative coefficient of $-0.002(t=-1.85)$ on Tenure in the REM_Index, Abn_CFO,Abn_Prod, and Abn_Discexp regressions, respectively. These results suggest that longer auditor tenure is associated with higher overall levels of real earnings management, lower abnormal cash flow, higher abnormal production, and lower discretionary expenses. Thus, collectively, these results suggest that longer auditor tenure is associated with more extensive real earnings management. This finding adds important insights into the debate regarding whether auditor rotation should be mandated. Past research has exclusively focused on whether longer or shorter auditor tenure is associated with lower accrual earnings management to infer whether mandatory auditor rotation is beneficial. Our paper adds 
an important piece in the literature by alerting regulators and researchers to the association between auditor tenure and real earnings management. Our finding of a positive association suggests to the policy makers a potential benefit of mandating auditor rotation, which has been missing in past debates.

\section{Additional Analyses}

Audit Fees as an Alternative Proxy for Audit Quality

Prior work (DeFond et al. 2000; Francis 2004) suggests that audit fees could serve as an overall indicator of audit quality to the extent that audit fees capture higher level of auditor effort. Thus, as before, we expect that firms will resort to more real earnings management when their ability to manage earnings via accruals is constrained by higher quality auditors that charge higher audit fees. We test our prediction with the following regression model (3), which in essence replaces auditor industry expertise variables, the Big $\mathrm{N}$ indicator, and auditor tenure in model (1) with an audit fee variable:

$$
\begin{aligned}
\text { REM }_{t}= & a_{0}+a_{1} * \text { LAudFees }_{t}+a_{2} * \text { Lev }_{t-1}+a_{3} * \text { LMVE }_{t-1}+a_{4} * M T B_{t-1}+a_{5} * \Delta E_{t-1}+a_{6} * \text { ROA }_{t-1}+ \\
& a_{7} * \text { ExOption }_{t}+a_{8} * \text { UnOption }_{t}+a_{9} * \text { Owner }_{t}+a_{10} * \text { Bonus }_{t}+e_{t}
\end{aligned}
$$

where

LAudFees $=$ Natural logarithm of audit fees from Audit Analytics 
All other variables are as defined before. We expect the coefficient on LAudFees in model (3) to be positive when we use REM_Index as the dependent variable. When we use each of its three components, Abn_CFO,Abn_Prod, and Abn_Discexp, as the dependent variable, we expect the coefficient on LAudFees to be negative, positive, and negative, respectively. Table 6 presents the regression results. ${ }^{8}$ Consistent with our expectations, we find a positive coefficient of 0.257 ( $t=3.37)$ on LAudFees in the REM_Index regression, suggesting that higher audit fees are associated with more overall real earnings management. We also find a negative coefficient of $-0.015(t=-4.31)$, a positive coefficient of $0.031(t=2.83)$, and a negative coefficient of -0.026 ( $t=-2.61)$ on LAudFees in the Abn_CFO,Abn_Prod, and Abn_Discexp regressions, respectively. These results suggest that higher levels of audit fees are associated with lower levels of abnormal cash flow, higher abnormal production, and lower discretionary expenses. Thus, collectively, these results suggest that higher overall audit quality as proxied by higher audit fees is associated

\footnotetext{
${ }^{8}$ We first confirm using our sample that audit fees are negatively associated with accrual earnings management. We run the following regression model extending Cohen et al. (2008): $D A_{t}=a_{0}+a_{1} * L A u d F e e s_{t}+a_{2} * L_{e v} v_{t-1}$ $+a_{3} * L_{M V E_{t-1}}+a_{4} * M_{t-1}+a_{5} * \Delta E_{t-1}+a_{6} * R O A_{t-1}+a_{7} * E_{\text {ExOption }}+a_{8} *$ UnOption $_{t}+a_{9} *$ Owner $_{t}+a_{10} *$ Bonus $_{t}+e_{t}$. We find a negative coefficient of -0.009 ( $t=-2.89)$ on LAudFees. Our results are consistent with the notion that higher audit fees can serve as an overall proxy for higher audit quality, which constrains accrual management. Furthermore, our model (2) results are robust to adding $D A$ as a control variable.
} 
with more real earnings management, an unintended consequence of hiring a higher quality auditor to constrain accrual earnings management.

\section{Individual Incentives for Upward Earnings Management}

Our main analyses pool all firms that we identify as having at least one of the four incentives for upward earnings management, i.e., firms that meet or just beat the three earnings benchmarks (zero earnings, previous year's earnings, and analyst forecasts) or firms that issue seasoned equities. In this analysis, we separately investigate each individual incentive: 54 (1.4 percent) of our 3,904 firm-year observations (see Table 1) meet or just beat the zero earnings benchmark, 221 (5.7 percent) meet or just beat the previous year's earnings benchmark, 380 (9.7 percent) meet or just beat analyst forecasts, and 362 (9.3 percent) issue seasoned equity offerings.

For each of the four sub-samples, we re-run model (1). Due to the smaller sample sizes, the coefficients on IndExp_city and BigN are insignificant in some regressions. However, in all cases, their signs are consistent with our predictions. Furthermore, for the 221 observations that meet or just beat the previous year's earnings benchmark, the coefficients on BigN are all significant at the $10 \%$ level in all four real earnings management regressions (i.e., REM_Index, Abn_CFO,Abn_Prod, and Abn_Discexp regressions). For the 380 observations that meet or just beat analyst forecasts, the coefficients on IndExp_city are all significant at the $10 \%$ level in all 
four real earnings management regressions. For the 362 observations that issue seasoned equities, the coefficients on and IndExp_city and BigN are all significant at the $10 \%$ level in all four real earnings management regressions. Thus, overall, we find consistent evidence that higher quality auditors are associated with more extensive real earnings management when firms have incentives to manage earnings upwards.

Comparing with Firms without Clear Incentives to Manage Earnings Upwards

Although our proxies for real earnings management are widely used in the literature (Roychowdhury 2006; Cohen et al. 2008; Cohen and Zarowin 2010), these proxies may measure real earnings management with error. If these measurement errors are correlated with our proxies for audit quality due to unobservable firm characteristics, the relation we document between audit quality and real earnings management could be spurious. We address this issue by demonstrating that the association between our real earnings management proxies and audit quality proxies is significantly stronger among firms that have strong incentives to management earnings upwards (our main sample, Incentive $=1$ ) than among firms that lack these incentives (Incentive $=0){ }^{9}$ The variable Incentive is an indicator variable that is coded as 1 for firms that have strong incentives to manage earnings upwards, i.e., firms that meet or just beat earnings

\footnotetext{
${ }^{9} \mathrm{We}$ thank an anonymous reviewer for pointing out this issue and for suggesting this solution.
} 
benchmarks (zero earnings, previous year's earnings, and analyst forecasts) and firms that issue seasoned equities, and 0 otherwise.

Table 1 shows that we have 925 observations in the Incentive=1 sample and 2,979 observations for the Incentive $=0$ sample. We run model (1) for the Incentive $=1$ and Incentive $=0$ samples, respectively, and report results of the comparison in Table 7. For brevity, we only show the coefficients of the audit quality proxies (IndExp_city, IndExp_national, and BigN). Note that the coefficients for the Incentive=1 sample are replicates of those reported in Table 5.

We test whether the coefficients are statistically different for the two samples (Incentive $=1$ vs. 0 ) by performing the Chow test. ${ }^{10}$ Our results support our prior conclusion that city-level industry expertise is associated with a greater extent of real earnings management because the difference in the coefficients on IndExp_city for the Incentive $=1$ and Incentive $=0$

\footnotetext{
${ }^{10}$ We perform the Chow test as detailed in http://www.stata.com/support/faqs/stat/chow3.html. Specifically, we pool the Incentive $=1$ and Incentive $=0$ samples together $(\mathrm{N}=3,904)$, and create interactions of Incentive with each of the independent variables in model (1) (i.e., 1, audit quality proxies, and control variables) and expand model (1) by including all the interactions. The coefficients on the interactions between the audit quality proxies and Incentive (i.e., IndExp_city*Incentive, IndExp_national*Incentive, and BigN*Incentive) are reported in the Difference rows along with their associated $t$-statistics. However, we caution the readers when interpreting the statistical significance of the differences (i.e., the interaction terms) due to the presence of potential multicollinearity problems in the Chow test regressions. We find that the collinearity condition index is 46 and the highest variance inflation factor is 60 . Thus, the multicollinearity problem could partially explain our failure to find significant differences of the impact of IndExp_national and BigN on real earnings management between the Incentive $=1$ and Incentive $=0$ samples.
} 
samples is significantly positive in the REM_Index regression $(0.620, t=2.31)$ and the Abn_Prod regression $(0.083, t=2.26)$, and significantly negative in the Abn_Descexp regression $(-0.088, t=$ -2.77). We do not find evidence that national level industry expertise or the presence of a big $\mathrm{N}$ audit firm is associated with real earnings management. A potential explanation for this lack of findings is that city-level industry expertise subsumes the effect of national level industry expertise and the presence of a big $\mathrm{N}$ audit firm as suggested by prior research (e.g., Reichelt and Wang 2010). Besides, 97 percent of our pooled sample (Incentive $=0$ plus Incentive $=1$ samples) has Big $\mathrm{N}$ auditors, suggesting a lack of variation in the $B i g N$ variable. Taken together, our results provide strong evidence that audit quality as proxied by city-level industry expertise is associated with greater extent of real earnings management.

\section{Conclusion}

The literature suggests that higher audit quality constrains accrual earnings management.

However, firms could resort to real earnings management when their opportunities for accrual earnings management are constrained. We examine whether higher audit quality has the unintended consequence of being associated with greater levels of real earnings management among firms with incentives to manage earnings. Our primary proxies for audit quality are auditor industry expertise and the presence of a Big $\mathrm{N}$ audit firm. For a sample of firms that 
manage earnings upwards (i.e., firms that meet or just beat earnings benchmarks and firms that issue seasoned equities), we find that city-level auditor industry expertise and the presence of a Big $\mathrm{N}$ audit firm are both associated with greater overall real earnings management. City-level auditor industry expertise is also associated with each individual component of real earnings management, i.e., lower abnormal cash flow, higher over-production, and lower discretionary expenditures, whereas Big $\mathrm{N}$ audit firms are associated with lower abnormal cash flow. Using audit fees as an additional proxy for audit quality, our findings confirm our primary results that higher audit quality is associated with more real earnings management. We further find that the positive association between city-level industry expertise and real earnings management measures is significantly stronger for the upward earnings management sample than for the sample where such incentives are absent. Our results suggest that imposition of higher levels of audit quality could result in unintended consequences. Monitoring bodies, such as boards and audit committees, should consider implications of imposing higher quality auditing, which could drive firms to potentially value-decreasing real earnings management activities.

Regulators have been repeatedly debating whether to mandate audit firm rotation (AICPA 1978, 1992; SOX 2002; GAO 2003; Cox 2006). The main concern is that that longer auditor tenure would foster an overly friendly relationship between the management and the auditor, which would in turn impair audit quality. Prior empirical studies have exclusively 
focused on examining the association between auditor tenure and accrual earnings management (Johnson et al. 2002; Myers et al. 2003). When they find a negative association between auditor tenure and abnormal accruals, they conclude that their findings do not support regulator concerns. Our results suggest that there is another important side of the story potentially missing in prior research. We find that longer auditor tenure is associated with more extensive real earnings management. Our results suggest that there could be some merits to mandating audit firm rotation because shortened auditor tenure could be associated with lower levels of real earnings management. Hence, our results would provide important additional inputs to policy makers when they consider whether to mandate audit firm rotation.

Past research on real earnings management (Roychowdhury 2006; Cohen and Zarowin 2010) has exclusively focused on upward earnings management. An interesting question for future research is whether and how firms take real actions to manage earnings downwards in certain contexts. Furthermore, what is the association between audit quality and downward real earnings management? Downward real earnings management seems a fruitful area for future research. 


\section{References:}

American Institute of Certified Public Accountants (AICPA). 1978. The Commission on Auditors' responsibilities: Report, conclusions and recommendations. New York: AICPA.

American Institute of Certified Public Accountants (AICPA). 1992. SEC practice section: Statement of position regarding mandatory rotation of audit firms of publicly held companies. New York: AICPA.

Balsam, S., J. Krishnan, and J. Young. 2003. Auditor industry specialization and earnings quality. Auditing: Journal of Practice and Theory 22 (2): 71-97.

Becker, C., M. DeFond, J. Jiambalvo, and K.R. Subramanyam. 1998. The effect of audit quality on earnings management. Contemporary Accounting Research 15 (1): 1-24.

Carcello, J. and A. Nagy. 2004. Client size, auditor specialization and fraudulent Financial Reporting. Managerial Auditing Journal 19 (5): 655-668.

Cohen, D., A. Dey, and T. Lys. 2008. Real and accrual-based earnings management in the pre and post-Sarbanes-Oxley periods. The Accounting Review 83 (3): 757-787.

Cohen, D., and P. Zarowin. 2010. Accrual-based and real earnings management activities around seasoned equity offerings. Journal of Accounting and Economics 50 (1): 2-19.

Cohen, D. and P. Zarowin. 2009. Earnings management and excess investment: Accrual vs. real activities manipulation. NYU Working paper.

Cox, C. 2006. Testimony concerning the impact of the Sarbanes-Oxley Act by the chair of the U.S. Securities and Exchange Commission before the U.S. House Committee on Financial Services, September 19.

Craswell, A., J. Francis, and S. Taylor. 1995. Auditor brand name reputations and industry specializations. Journal of Accounting and Economics 20 (3): 297-322.

Davis, L., B. Soo, and G. Trometer (2009). Auditor tenure and the ability to meet or beat earnings forecasts. Contemporary Accounting Research 26 (2): 517-548. 
DeFond, M. L., J. R. Francis, and T. J. Wong. 2000. Auditor industry specialization and market segmentation: Evidence from Hong Kong. Auditing: A Journal of Practice and Theory 19 (1): 49-66.

Dunn, K., and B. Mayhew. 2004. Audit firm industry specialization and client disclosure quality. Review of Accounting Studies 9 (1): 35-58.

Ewert, R., and A. Wagenhofer. 2005. Economic effects of tightening accounting standards to restrict earnings management. The Accounting Review 80 (4): 1101-1125.

Ferguson, A., J. Francis, and D. Stokes. 2003. The effects of firm-wide and office-level industry expertise on audit pricing. The Accounting Review 78 (2): 429-448.

Firth, M. and A. Smith. 1992. Selection of auditor firms by companies in the new issue market. Applied Economics 24: 247-255.

Francis, J. 2004. What do we know about audit quality? The British Accounting Review 36 (4): 345-68.

Francis, J., K. Reichelt, and D. Wang. 2005. The pricing of national and city-specific reputations for industry expertise in the U.S. audit market. The Accounting Review 80 (1): 113-136.

General Accounting Office (GAO). 2003. Public accounting firms: Required study on the potential effects of mandatory audit firm rotation. Washington, DC:GAO.

Gong, G., H. Louis, and A. Sun, 2008. Earnings management and firm performance following open-market repurchases. Journal of Finance 63 (2): 947-986.

Gow, I. D., G. Ormazabal, and D. J. Taylor. 2010. Correcting for Cross-Sectional and TimeSeries Dependence in Accounting Research. The Accounting Review 85 (2): 483-512.

Griffin, P, A. Li, and D. Lont. 2009. Non-audit fees, audit tenure and auditor independence: evidence from going concern opinions. University of California, Working Paper. 
Gupta, M., M. Pevzner, C. Seethamraju. 2010. Implications of absorption costing for future firm performance and valuation. Contemporary Accounting Research 27 (3): 889-922.

Jones, J. 1991. Earnings management during import relief investigations. Journal of Accounting Research 29 (2): 193-228.

Johnson, V., A. Khurana, and K. Reynolds. 2002. Audit-firm tenure and the quality of financial reports. Contemporary Accounting Research 19 (4): 637-660.

Kim, B, M. Pevzner, and L. Lei. 2010. Debt covenant slacks and real earnings management. George Mason University Working Paper.

Knechel, W. R., V. Naiker, and G. Pacheko. 2007. Does auditor industry specialization matter? Evidence from market reaction to auditor switches. Auditing: A Journal of Practice and Theory 26 (1): 19-45.

Kothari, S. P., A. Leone, and C. Wasley. 2005. Performance-matched discretionary accruals measures. Journal of Accounting and Economics 39: 163-197.

Krishnan, G. 2003. Does Big 6 auditor industry expertise constrain earnings management? Accounting Horizons 17: 1-16.

Lennox, C. 1999. Are large auditors more accurate than small auditors? Accounting and Business Research 29 (3): 217-227.

Lys, T., and R. L. Watts. 1994. Lawsuits against auditors. Journal of Accounting Research 32: 65-93.

Myers, J, Myers, L., and T. Omer. 2003. Exploring the term of auditor-client relationship and quality of earnings: the case for mandatory auditor rotation. The Accounting Review 78 (3): 779-799.

Nichols, D. and D. Smith. 1983. Auditor credibility and auditor changes. Journal of Accounting Research 72: 385-406. 
Reichelt, K. J., and D. Wang. 2010. National and office-specific measures of auditor industry expertise and effects on audit quality. Journal of Accounting Research 48 (3): 647-686.

Romanus R. N., J. J. Maher, and D. M. Fleming. 2008. Auditor industry specialization, auditor changes, and accounting restatements. Accounting Horizons 22 (4): 389-413.

Roychowdhury, S. 2006. Earnings management through real activities manipulation. Journal of Accounting and Economics 42 (3): 335-370.

Teoh, S. H., I. Welch, and T. J. Wong. 1998. Earnings management buyout offers. Journal of Finance 53 (6): 1935-1974.

Teoh, S. H., and T. J. Wong. 1993. Perceived auditor quality and the earnings response coefficient. The Accounting Review 68 (2): 346-366.

Yu, W. 2008. Accounting-based earnings management and real activities manipulation. Georgia Tech University, Dissertation.

Zang, A. 2007. Evidence on the tradeoff between real manipulation and accrual manipulation. Hong Kong University of Science and Technology, Working Paper. 


\section{Appendix}

\section{Variables Definitions:}

REM

IndExp_city

IndExp_national

BigN

Tenure

Lev

LMVE

$M T B$

$\Delta E$

$R O A$

ExOption

UnOption

Owner

Bonus

$D A$

Incentive
Real earnings management variables defined based on Cohen et al. (2008): $A b n \_C F O$ : Abnormal cash flows (negative measure of real earnings management)

Abn_Prod: Abnormal inventory over-production (positive measure of real earnings management)

Abn_Discexp: Abnormal discretionary expenses (negative measure of real earnings management)

REM_Index: - standardized Abn_CFO + standardized Abn_Prod standardized Abn_Discexp (positive composite score of real earnings management). Standardized measure for each variable $=$ [variable mean(variable)] / standard deviation(variable)

Audit fee market share of the local office of auditor in the city-industry combination

Audit fee market share of the auditor in the industry

$=1$ if auditor is a Big $\mathrm{N}$ audit firm, and 0 otherwise

Number of years the auditor has audited the company's financial statements

A firm's leverage defined as the ratio of total liabilities to assets

Natural log of market value of equity for a firm

A firm's market-to-book ratio

Change in a firm's annual earnings, deflated by prior year assets

A firm's return on assets defined as the ratio of earnings before extraordinary items deflated by prior period assets

Value of executive exercisable (i.e., vested) options at the end of the year from ExecuComp

Value of executive un-exercisable (i.e., un-vested) options at the end of the year from ExecuComp

The sum of restricted stock grants in the current period and the aggregate number of shares held by the executive at year-end (excluding stock options) scaled by total outstanding shares of the firm, computed using ExecuComp data

Average bonus compensation as a proportion of total compensation received by the $\mathrm{CEO}$ and the $\mathrm{CFO}$ of the firm from Execucomp

Modified Jones (1991) model of discretionary accruals, with control for contemporaneous accounting performance as suggested in Kothari et al (2005)

$=1$ for firms that have strong incentives to manage earnings upwards (indentified ex post or ex ante), i.e., firms that meet or just beat earnings benchmarks (zero earnings, previous year's earnings, and analyst forecasts) and firms that issue seasoned equities, and 0 otherwise 
TABLE 1

\section{Sample Selection}

Audit fees coverage in Audit Analytics from 2001 to 2008

Firm-year Obs.

Financial institutions or utility firms, or not covered by Compustat

Missing data to calculate real earnings management measures

Missing data for additional Compustat control variables (e.g., auditor tenure, leverage, firm size, earnings level and change, and market to book ratio)

Missing data for Execucomp control variables (i.e., option holdings, bonus, and ownership)

Observations with available data for all regression models 3,904

Observations without clear incentives to manage earnings upwards

Final sample: Observations with upward earnings management incentives (i.e., firms that meet or just beat zero earnings, previous year's earnings, or analyst forecasts benchmarks, or firms that issue seasoned equities) 


\section{TABLE 2}

\section{Descriptive Statistics}

The table summarizes descriptive statistics for our sample. Panels A-C present distributions of the estimated coefficients and $\mathrm{R}^{2} \mathrm{~s}$ from the industry-year regression results that estimate the components of real earnings management (i.e., Abn_CFO,Abn_Prod, and Abn_Discexp). These regressions are based on all observations in Compustat with available data for Models (A)-(C) before we implement additional data requirements for Model (1). We require at least 15 observations in each industry-year group. There are 337 such industry-year groups from 2001 to 2008. Panel D provides descriptive statistics for all variables in our regression model (1).

\begin{tabular}{|c|c|c|c|c|c|}
\hline \\
\hline \multicolumn{6}{|c|}{ Panel A: Distribution of estimated coefficients and $\mathrm{R}^{2} \mathrm{~s}$ from $\operatorname{Model}(\mathrm{A})$ to calculate Abn_CFO } \\
\hline $1 /$ Assets $_{\mathrm{t}-1}$ & -0.902 & 2.038 & -0.689 & -0.482 & -0.260 \\
\hline Sales $_{\mathrm{t}} /$ Assets $_{\mathrm{t}-1}$ & 0.063 & 0.059 & 0.032 & 0.053 & 0.079 \\
\hline$\Delta$ Sales $_{\mathrm{t}} /$ Assets $_{\mathrm{t}-1}$ & -0.004 & 0.209 & -0.082 & 0.008 & 0.099 \\
\hline Adj. $\mathrm{R}^{2}$ & 0.535 & 0.243 & 0.373 & 0.555 & 0.714 \\
\hline \multicolumn{6}{|c|}{ Panel B: Distribution of estimated coefficients and $\mathrm{R}^{2}$ s from Model (B) to calculate Abn_Prod } \\
\hline & Mean & Std. Dev. & Q1 & Median & Q3 \\
\hline $1 /$ Assets $_{\mathrm{t}-1}$ & -0.649 & 4.252 & -0.227 & -0.004 & 0.047 \\
\hline Salest $_{\mathrm{t}} /$ Assets $_{\mathrm{t}-1}$ & 0.708 & 0.111 & 0.647 & 0.717 & 0.788 \\
\hline$\Delta$ Sales $_{\mathrm{t}}$ /Assets $_{\mathrm{t}-1}$ & 0.031 & 0.348 & -0.084 & 0.036 & 0.149 \\
\hline$\Delta$ Sales $_{\mathrm{t}-1} /$ Assets $_{\mathrm{t}-1}$ & 0.004 & 0.294 & -0.121 & -0.019 & 0.085 \\
\hline Adj. $R^{2}$ & 0.935 & 0.088 & 0.933 & 0.965 & 0.984 \\
\hline \multicolumn{6}{|c|}{ Panel C: Distribution of estimated coefficients and $\mathrm{R}^{2} \mathrm{~s}$ from Model $(\mathrm{C})$ to calculate Abn_Discexp } \\
\hline & Mean & Std. Dev. & Q1 & Median & Q3 \\
\hline $1 /$ Assets $_{\mathrm{t}-1}$ & 2.110 & 5.400 & 0.796 & 1.173 & 1.506 \\
\hline Sales $_{\mathrm{t}-1} /$ Assets $_{\mathrm{t}-1}$ & 0.226 & 0.127 & 0.132 & 0.210 & 0.314 \\
\hline Adj. $\mathrm{R}^{2}$ & 0.739 & 0.171 & 0.649 & 0.740 & 0.880 \\
\hline
\end{tabular}




\begin{tabular}{lccccc}
\hline Panel D: Distribution of all variables & & & & \\
Variable & Mean & Std. Dev. & Q1 & Median & Q3 \\
REM_Index $_{\mathrm{t}}$ & -0.230 & 1.584 & -1.155 & -0.227 & 0.539 \\
Abn_CFO $_{\mathrm{t}}$ & 0.055 & 0.116 & 0.003 & 0.054 & 0.113 \\
Abn_Prod & -0.048 & 0.210 & -0.168 & -0.052 & 0.046 \\
Abn_Discexp & 0.026 & 0.245 & -0.078 & 0.021 & 0.137 \\
IndExp_city & 0.488 & 0.287 & 0.248 & 0.464 & 0.714 \\
IndExp_national $_{\mathrm{t}}$ & 0.245 & 0.098 & 0.182 & 0.244 & 0.307 \\
BigN $_{\mathrm{t}}$ & 0.968 & 0.175 & 1.000 & 1.000 & 1.000 \\
Tenure $_{\mathrm{t}}$ & 12.872 & 8.945 & 6.000 & 10.000 & 17.000 \\
Lev $_{\mathrm{t}-1}$ & 0.549 & 0.356 & 0.342 & 0.514 & 0.672 \\
LMVE $_{\mathrm{t}-1}$ & 7.326 & 1.650 & 6.251 & 7.193 & 8.434 \\
MTB $_{\mathrm{t}-1}$ & 3.283 & 5.208 & 1.573 & 2.410 & 3.952 \\
$\Delta \mathrm{E}_{\mathrm{t}-1}$ & 0.018 & 0.197 & -0.012 & 0.013 & 0.036 \\
ROA $_{\mathrm{t}-1}$ & 0.045 & 0.184 & 0.017 & 0.061 & 0.106 \\
ExOption $_{\mathrm{t}}$ & 6.467 & 7.560 & 1.490 & 4.037 & 8.457 \\
UnOption $_{\mathrm{t}}$ & 3.254 & 3.859 & 0.718 & 2.058 & 4.355 \\
Owner $_{\mathrm{t}}$ & 17.070 & 37.335 & 0.797 & 3.262 & 13.292 \\
Bonus $_{\mathrm{t}}$ & 0.165 & 0.167 & 0.000 & 0.124 & 0.278 \\
\hline
\end{tabular}


TABLE 3

\section{Correlation Matrix}

\begin{tabular}{|c|c|c|c|c|c|c|c|c|c|c|c|c|c|c|c|c|c|}
\hline & (A) & (B) & (C) & (D) & (E) & (F) & (G) & $(\mathrm{H})$ & (I) & (J) & $(\mathrm{K})$ & (L) & (M) & $(\mathrm{N})$ & (O) & $(\mathrm{P})$ & (Q) \\
\hline REM_Index $(\mathrm{A})$ & & $-0.627^{*}$ & $0.965^{*}$ & $-0.776^{*}$ & $0.081^{*}$ & 0.024 & 0.016 & $0.050^{*}$ & $0.198^{*}$ & $-0.176^{*}$ & $-0.361^{*}$ & $-0.149^{*}$ & $-0.369^{*}$ & -0.014 & $-0.048^{*}$ & $0.041^{*}$ & $-0.050^{*}$ \\
\hline $\mathrm{Abn} \_\mathrm{CFO} \mathrm{t}_{\mathrm{t}}(\mathrm{B})$ & $-0.542^{*}$ & & $-0.508^{*}$ & $0.156^{*}$ & $-0.051^{*}$ & $-0.027^{*}$ & -0.015 & $-0.044^{*}$ & $-0.134^{*}$ & $0.292^{*}$ & $0.430^{*}$ & $0.193^{*}$ & $0.569^{*}$ & $-0.069^{*}$ & -0.018 & $-0.045^{*}$ & $0.083^{*}$ \\
\hline Abn_Prod ${ }_{t}(C)$ & $0.971^{*}$ & $-0.416^{*}$ & & $-0.759^{*}$ & $0.077^{*}$ & $0.028^{*}$ & 0.020 & $0.040^{*}$ & $0.171^{*}$ & $-0.164^{*}$ & $-0.330^{*}$ & $-0.122^{*}$ & $-0.327^{*}$ & -0.011 & $-0.040^{*}$ & $0.032^{*}$ & $-0.036^{*}$ \\
\hline Abn_Discexp $(\mathrm{D})$ & $-0.774^{*}$ & $-0.043^{*}$ & $-0.760^{*}$ & & $-0.096^{*}$ & -0.020 & -0.022 & $-0.040^{*}$ & $-0.219^{*}$ & -0.001 & $0.165^{*}$ & $0.066^{*}$ & $0.045^{*}$ & $0.090^{*}$ & $0.097^{*}$ & $-0.033^{*}$ & 0.011 \\
\hline $\operatorname{IndExp}_{-} \mathrm{City}_{\mathrm{t}}(\mathrm{E})$ & $0.076^{*}$ & -0.020 & $0.069^{*}$ & $-0.087^{*}$ & & $0.337^{*}$ & $0.203^{*}$ & $0.063^{*}$ & $0.186^{*}$ & $0.220^{*}$ & $0.022^{*}$ & -0.009 & $0.036^{*}$ & $-0.108^{*}$ & $-0.074^{*}$ & $-0.037^{*}$ & $0.029^{*}$ \\
\hline IndExp_National $_{t}(\mathrm{~F})$ & $0.033^{*}$ & -0.003 & $0.033^{*}$ & $-0.038^{*}$ & $0.357^{*}$ & & $0.415^{*}$ & -0.004 & $0.076^{*}$ & $0.141^{*}$ & -0.003 & 0.023 & 0.005 & $-0.097^{*}$ & $-0.059^{*}$ & $-0.070^{*}$ & $0.047^{*}$ \\
\hline $\operatorname{BigN}_{t}(G)$ & $0.033^{*}$ & -0.002 & $0.031^{*}$ & $-0.041^{*}$ & $0.215^{*}$ & $0.302^{*}$ & & $0.050^{*}$ & $0.092^{*}$ & $0.135^{*}$ & $0.042^{*}$ & -0.013 & -0.019 & $-0.068^{*}$ & $0.029^{*}$ & $-0.059^{*}$ & 0.021 \\
\hline Tenure $_{t}(\mathrm{H})$ & $0.079^{*}$ & $-0.042^{*}$ & $0.067^{*}$ & $-0.077^{*}$ & $0.085^{*}$ & 0.011 & $0.063^{*}$ & & $0.078^{*}$ & $0.142^{*}$ & -0.004 & $-0.067^{*}$ & -0.016 & $-0.097^{*}$ & $-0.126^{*}$ & $-0.051^{*}$ & -0.023 \\
\hline $\operatorname{Lev}_{t-1}(\mathrm{I})$ & $0.099^{*}$ & $-0.167^{*}$ & $0.072^{*}$ & -0.012 & $0.116^{*}$ & $0.064^{*}$ & 0.025 & $0.050^{*}$ & & $0.186^{*}$ & $0.058^{*}$ & $-0.035^{*}$ & $-0.051^{*}$ & $-0.103^{*}$ & $-0.090^{*}$ & -0.021 & $0.092^{*}$ \\
\hline $\operatorname{LMVE}_{\mathrm{t}-1}(\mathrm{~J})$ & $-0.170^{*}$ & $0.275^{*}$ & $-0.148^{*}$ & -0.005 & $0.207^{*}$ & $0.153^{*}$ & $0.144^{*}$ & $0.153^{*}$ & $0.082^{*}$ & & $0.507^{*}$ & $0.032^{*}$ & $0.354^{*}$ & $-0.380^{*}$ & $-0.285^{*}$ & $-0.265^{*}$ & 0.018 \\
\hline $\operatorname{MTB}_{\mathrm{t}-1}(\mathrm{~K})$ & $-0.189^{*}$ & $0.211^{*}$ & $-0.168^{*}$ & $0.074^{*}$ & -0.015 & -0.015 & 0.015 & -0.001 & 0.025 & $0.225^{*}$ & & $0.113^{*}$ & $0.537^{*}$ & $-0.141^{*}$ & $-0.048^{*}$ & $-0.114^{*}$ & $-0.028^{*}$ \\
\hline$\Delta \mathrm{E}_{\mathrm{t}-1}(\mathrm{~L})$ & $-0.035^{*}$ & -0.021 & $-0.039^{*}$ & $0.054^{*}$ & -0.017 & 0.010 & 0.004 & $-0.048^{*}$ & $-0.046^{*}$ & $-0.048^{*}$ & $0.041^{*}$ & & $0.417^{*}$ & $-0.051^{*}$ & -0.012 & -0.002 & $0.138^{*}$ \\
\hline $\mathrm{ROA}_{\mathrm{t}-1}(\mathrm{M})$ & $-0.196^{*}$ & $0.604^{*}$ & $-0.151^{*}$ & $-0.233^{*}$ & $0.070^{*}$ & $0.047^{*}$ & $0.060^{*}$ & 0.011 & $-0.268^{*}$ & $0.246^{*}$ & $0.146^{*}$ & $0.126^{*}$ & & $-0.107^{*}$ & $-0.083^{*}$ & -0.005 & $0.072^{*}$ \\
\hline ExOption $_{t}(\mathrm{O})$ & $-0.042^{*}$ & $-0.115^{*}$ & $-0.056^{*}$ & $0.133^{*}$ & $-0.095^{*}$ & $-0.090^{*}$ & $-0.079^{*}$ & $-0.102^{*}$ & -0.022 & $-0.359^{*}$ & $-0.068^{*}$ & -0.019 & $-0.123^{*}$ & & $0.415^{*}$ & $0.228^{*}$ & -0.014 \\
\hline UnOption $_{\mathrm{t}}(\mathrm{P})$ & $-0.029^{*}$ & $-0.066^{*}$ & $-0.033^{*}$ & $0.087^{*}$ & $-0.066^{*}$ & $-0.052^{*}$ & 0.022 & $-0.130^{*}$ & $-0.030^{*}$ & $-0.308^{*}$ & $-0.037^{*}$ & $0.028^{*}$ & $-0.087^{*}$ & $0.351^{*}$ & & $0.067^{*}$ & $0.099^{*}$ \\
\hline Owner $_{t}(\mathrm{Q})$ & $0.050^{*}$ & $-0.029^{*}$ & $0.044^{*}$ & $-0.044^{*}$ & -0.001 & $-0.030^{*}$ & $-0.072^{*}$ & -0.023 & -0.025 & $-0.171^{*}$ & $-0.037^{*}$ & -0.021 & -0.001 & $0.116^{*}$ & $0.041^{*}$ & & 0.015 \\
\hline Bonus $_{t}(\mathrm{R})$ & $-0.043^{*}$ & $0.060^{*}$ & $-0.036^{*}$ & 0.011 & $0.035^{*}$ & $0.046^{*}$ & 0.014 & -0.006 & $0.077^{*}$ & 0.020 & -0.018 & 0.013 & $0.034^{*}$ & -0.020 & $0.118^{*}$ & -0.004 & \\
\hline
\end{tabular}

See Appendix for variable definitions. Pearson correlations in the lower diagonal and Spearman correlations in the upper diagonal. * indicates significance at the $10 \%$ level. 


\section{TABLE 4}

\section{Audit Quality and Accrual earnings management}

The table summarizes the regression of modified Jones model abnormal accruals adjusted for contemporaneous accounting performance on audit quality proxies such as city- and national level industry expertise variables, audit firm size, and associated control variables for the sample of firms that have strong incentives to manage earnings upwards, i.e., firms that meet or just beat earnings benchmarks (zero earnings, previous year's earnings and analyst forecasts) and firms that issue seasoned equity offerings. The model includes year fixed effects, and the $t$-statistics in parentheses are based on the two-way cluster-robust standard errors (cluster by firm and by year), which adjust for both cross-sectional and time-series dependence in panel data. All continuous variables are winsorized at $1^{\text {st }}$ and $99^{\text {th }}$ percentiles. $*, * *, * * *$ denote $0.1,0.05$, and 0.01 significance levels, respectively. All variables are defined in the Appendix.

\begin{tabular}{llc}
\hline & $\mathrm{DA}$ & $t$-stat \\
\hline Intercept $_{\text {IndExp_city }}$ & $-0.058^{*}$ & -1.90 \\
IndExp_national $_{\mathrm{t}}$ & $-0.020^{* * *}$ & -3.30 \\
BigN $_{\mathrm{t}}$ & -0.014 & -0.67 \\
Tenure $_{\mathrm{t}}$ & $-0.019^{*}$ & -1.65 \\
Lev $_{\mathrm{t}-1}$ & $-0.001^{* * *}$ & -4.63 \\
LMVE $_{\mathrm{t}-1}$ & 0.014 & 1.58 \\
$\mathrm{MTB}_{\mathrm{t}-1}$ & $-0.010^{* * *}$ & -3.36 \\
$\Delta \mathrm{E}_{\mathrm{t}-1}$ & $-0.003^{* * *}$ & -3.12 \\
ROA $_{\mathrm{t}-1}$ & $0.087^{*}$ & 1.78 \\
ExOption $_{\mathrm{t}}$ & 0.033 & 1.61 \\
UnOption $_{\mathrm{t}}$ & 0.000 & 1.30 \\
Owner $_{\mathrm{t}}$ & -0.000 & -0.60 \\
Bonus $_{\mathrm{t}}$ & $0.000^{* *}$ & 2.07 \\
Year Dummies $_{N}$ & $-0.044^{* * *}$ & -2.75 \\
\hline Adj. $R^{2}$ & Yes & \\
\hline
\end{tabular}




\section{TABLE 5}

\section{Audit Quality and Real Earnings Management}

The table summarizes the regression of real earnings management measures on audit quality proxies such as city- and national level industry expertise variables, audit firm size, and associated control variables for the sample of firms that have strong incentives to manage earnings upwards, i.e., firms that meet or just beat earnings benchmarks (zero earnings, previous year's earnings and analyst forecasts) and firms that issue seasoned equity offerings. All models include year fixed effects, and the $t$-statistics in parentheses are based on the two-way cluster-robust standard errors (cluster by firm and by year), which adjust for both cross-sectional and time-series dependence in panel data. All continuous variables are winsorized at $1^{\text {st }}$ and $99^{\text {th }}$ percentiles. $* * *, * * *$ denote $0.1,0.05$, and 0.01 significance levels, respectively. All variables are defined in the Appendix.

\begin{tabular}{|c|c|c|c|c|}
\hline & REM_Index & Abn_CFO & Abn_Prod & Abn_Discexp \\
\hline \multirow[t]{2}{*}{ Intercept } & -0.270 & $0.056^{* * *}$ & -0.072 & -0.002 \\
\hline & $(-0.74)$ & $(2.00)$ & $(-1.56)$ & $(-0.03)$ \\
\hline \multirow[t]{2}{*}{ IndExp_city } & $0.947^{* * *}$ & $-0.040^{* * *}$ & $0.119^{* * *}$ & $-0.113^{* * *}$ \\
\hline & $(3.54)$ & $(-3.02)$ & $(3.12)$ & $(-3.09)$ \\
\hline \multirow{2}{*}{ IndExp_national $_{t}$} & -0.206 & 0.010 & -0.018 & 0.037 \\
\hline & $(-0.38)$ & $(0.28)$ & $(-0.23)$ & $(0.45)$ \\
\hline \multirow{2}{*}{$\mathrm{BigN}_{\mathrm{t}}$} & $0.509^{*}$ & $-0.041^{*}$ & 0.051 & -0.048 \\
\hline & $(1.85)$ & $(-1.82)$ & $(1.45)$ & $(-0.97)$ \\
\hline \multirow[t]{2}{*}{ Tenure $_{t}$} & $0.019^{* *}$ & $-0.001^{* *}$ & $0.002^{* *}$ & $-0.002^{*}$ \\
\hline & $(2.46)$ & $(-2.58)$ & $(2.42)$ & $(-1.85)$ \\
\hline \multirow{2}{*}{$\operatorname{Lev}_{\mathrm{t}-1}$} & 0.296 & -0.003 & 0.028 & $-0.069^{\text {*** }}$ \\
\hline & $(1.49)$ & $(-0.44)$ & $(0.90)$ & $(-2.64)$ \\
\hline \multirow[t]{2}{*}{$\mathrm{LMVE}_{\mathrm{t}-1}$} & $-0.236^{* * *}$ & $0.014^{* * * *}$ & $-0.027^{* * * *}$ & $0.026^{* * *}$ \\
\hline & $(-4.47)$ & $(4.52)$ & $(-4.26)$ & $(3.11)$ \\
\hline \multirow{2}{*}{$\mathrm{MTB}_{\mathrm{t}-1}$} & $-0.065^{* * *}$ & $0.005^{* * *}$ & $-0.007^{* * *}$ & $0.006^{* *}$ \\
\hline & $(-3.01)$ & $(3.16)$ & $(-2.85)$ & $(2.08)$ \\
\hline \multirow{2}{*}{$\Delta \mathrm{E}_{\mathrm{t}-1}$} & 0.295 & $-0.066^{* *}$ & 0.072 & 0.130 \\
\hline & $(0.55)$ & $(-2.46)$ & $(1.16)$ & (1.04) \\
\hline \multirow[t]{2}{*}{$\mathrm{ROA}_{\mathrm{t}-1}$} & -0.536 & $0.223^{* * *}$ & -0.058 & $-0.299^{* * *}$ \\
\hline & $(-0.85)$ & $(7.01)$ & $(-0.73)$ & $(-3.11)$ \\
\hline \multirow{2}{*}{ ExOption $_{t}$} & $-0.019^{* * *}$ & 0.000 & $-0.002^{* * *}$ & $0.004^{* * *}$ \\
\hline & $(-3.00)$ & $(0.42)$ & $(-2.67)$ & (3.14) \\
\hline \multirow[t]{2}{*}{ UnOption $_{\mathrm{t}}$} & -0.024 & 0.001 & -0.002 & $0.003^{*}$ \\
\hline & $(-1.64)$ & $(1.59)$ & $(-1.11)$ & (1.77) \\
\hline \multirow[t]{2}{*}{ Owner $_{t}$} & 0.004 & $-0.000^{* * *}$ & 0.000 & -0.000 \\
\hline & $(1.31)$ & $(-2.82)$ & $(1.15)$ & $(-1.08)$ \\
\hline \multirow[t]{2}{*}{ Bonus $_{t}$} & $-0.797^{* * *}$ & $0.051^{\text {*** }}$ & $-0.093^{*}$ & 0.076 \\
\hline & $(-2.69)$ & (3.03) & $(-1.93)$ & (1.34) \\
\hline Year Dummies & Yes & Yes & Yes & Yes \\
\hline$N$ & 925 & 925 & 925 & 925 \\
\hline Adj. $R^{2}$ & 0.196 & 0.392 & 0.145 & 0.112 \\
\hline
\end{tabular}


TABLE 6

\section{Audit Fees and Real Earnings Management}

The table summarizes the regression of real earnings management measures on natural log of audit fees and associated control variables for the sample of firms that have strong incentives to manage earnings upwards, i.e., firms that meet or just beat earnings benchmarks (zero earnings, previous year's earnings and analyst forecasts) and firms that issue seasoned equity offerings. All models include year fixed effects, and the $t$ statistics in parentheses are based on the two-way cluster-robust standard errors (cluster by firm and by year), which adjust for both cross-sectional and time-series dependence in panel data. All continuous variables are winsorized at $1^{\text {st }}$ and $99^{\text {th }}$ percentiles. $*, * *, * *$ denote $0.1,0.05$, and 0.01 significance levels, respectively. All variables are defined in the Appendix.

\begin{tabular}{|c|c|c|c|c|}
\hline & REM_Index & Abn_CFO & Abn_Prod & Abn_Discexp \\
\hline \multirow[t]{2}{*}{ Intercept } & -0.239 & $0.050^{* *}$ & -0.073 & -0.007 \\
\hline & $(-0.51)$ & $(2.15)$ & $(-1.19)$ & $(-0.10)$ \\
\hline \multirow[t]{2}{*}{ LAudFees $_{t}$} & $0.257^{* * * *}$ & $-0.015^{* * *}$ & $0.031^{\text {**** }}$ & $-0.026^{* * * *}$ \\
\hline & $(3.37)$ & $(-4.31)$ & $(2.83)$ & $(-2.61)$ \\
\hline \multirow[t]{2}{*}{$\operatorname{Lev}_{t-1}$} & $0.338^{*}$ & -0.004 & 0.034 & $-0.076^{* * *}$ \\
\hline & $(1.96)$ & $(-0.59)$ & $(1.23)$ & $(-3.62)$ \\
\hline \multirow[t]{2}{*}{$\mathrm{LMVE}_{\mathrm{t}-1}$} & $-0.298^{* * *}$ & $0.018^{* * * *}$ & $-0.034^{* * * *}$ & $0.032^{* * *}$ \\
\hline & $(-5.39)$ & $(5.48)$ & $(-5.03)$ & $(3.71)$ \\
\hline \multirow[t]{2}{*}{$\mathrm{MTB}_{\mathrm{t}-1}$} & $-0.067^{\text {**** }}$ & $0.005^{* * *}$ & $-0.007^{* * *}$ & $0.006^{* *}$ \\
\hline & $(-3.26)$ & (3.18) & $(-3.13)$ & $(2.43)$ \\
\hline \multirow{2}{*}{$\Delta \mathrm{E}_{\mathrm{t}-1}$} & -0.271 & -0.034 & 0.004 & 0.189 \\
\hline & $(-0.68)$ & $(-1.45)$ & $(0.08)$ & (1.59) \\
\hline \multirow[t]{2}{*}{$\mathrm{ROA}_{\mathrm{t}-1}$} & -0.135 & $0.200^{* * * *}$ & -0.010 & $-0.341^{* * *}$ \\
\hline & $(-0.24)$ & (6.19) & $(-0.15)$ & $(-3.81)$ \\
\hline \multirow[t]{2}{*}{ ExOption $_{\mathrm{t}}$} & $-0.024^{* * * *}$ & 0.000 & $-0.003^{* * *}$ & $0.004^{* * *}$ \\
\hline & $(-3.75)$ & $(0.87)$ & $(-3.34)$ & (3.92) \\
\hline \multirow[t]{2}{*}{ UnOption $_{\mathrm{t}}$} & -0.017 & 0.001 & -0.002 & 0.003 \\
\hline & $(-1.19)$ & $(1.20)$ & $(-0.74)$ & $(1.41)$ \\
\hline \multirow[t]{2}{*}{ Owner $_{t}$} & 0.004 & $-0.000^{* * *}$ & 0.001 & -0.001 \\
\hline & $(1.42)$ & $(-3.08)$ & $(1.28)$ & $(-1.17)$ \\
\hline \multirow[t]{2}{*}{ Bonus $_{t}$} & $-1.043^{* * *}$ & $0.065^{* * *}$ & $-0.122^{* * *}$ & $0.102^{*}$ \\
\hline & $(-3.40)$ & $(3.38)$ & $(-2.63)$ & $(1.81)$ \\
\hline Year Dummies & Yes & Yes & Yes & Yes \\
\hline$N$ & 925 & 925 & 925 & 925 \\
\hline Adj. $R^{2}$ & 0.170 & 0.381 & 0.121 & 0.095 \\
\hline
\end{tabular}


TABLE 7

\section{Comparing with Firms without Clear Incentives to Manage Earnings Upwards}

The table compares the regression coefficients of real earnings management measures on audit quality proxies between the sample that has strong incentives to manage earnings upwards (Incentive=1) and the sample that does not have clear incentives to do so (Incentive=0). See Table 1 for sample selection procedures. The coefficients on audit quality proxies for the Incentive $=1$ sample replicate those presented in Table 5. Differences in coefficients are tested using the Chow test. $t$-statistics in parentheses are based on the two-way cluster-robust standard errors (cluster by firm and by year), which adjust for both crosssectional and time-series dependence in panel data. *, **, *** denote $0.1,0.05$, and 0.01 significance levels, respectively. All variables are defined in the Appendix.

\begin{tabular}{llcccc}
\hline & & REM_Index & Abn_CFO & Abn_Prod & Abn_Discexp \\
\hline \multirow{4}{*}{ IndExp_city } & Incentive=1 & $0.947^{* * * *}$ & $-0.040^{* * * *}$ & $0.119^{* * * *}$ & $-0.113^{* * * *}$ \\
& $(\mathrm{~N}=925)$ & $(3.54)$ & $(-3.02)$ & $(3.12)$ & $(-3.09)$ \\
& Incentive=0 & $0.327^{*}$ & $-0.026^{* * *}$ & 0.036 & -0.025 \\
& $(\mathrm{~N}=2,979)$ & $(1.78)$ & $(-3.11)$ & $(1.47)$ & $(-0.96)$ \\
& Difference & $0.620^{* *}$ & -0.014 & $0.083^{* *}$ & $-0.088^{* * *}$ \\
& & $(2.31)$ & $(-0.87)$ & $(2.26)$ & $(-2.77)$ \\
\hline \multirow{5}{*}{ IndExp_national } & Incentive=1 & -0.206 & 0.010 & -0.018 & 0.037 \\
& Incentive=0 & 0.110 & -0.009 & 0.016 & 0.001 \\
& (N=2,979) & $(0.18)$ & $(-0.33)$ & $(0.20)$ & $(0.01)$ \\
& Difference & -0.316 & 0.019 & -0.034 & 0.036 \\
& & $(-0.50)$ & $(0.46)$ & $(-0.39)$ & $(0.49)$ \\
\hline \multirow{5}{*}{ BigN } & Incentive=1 & $0.509^{*}$ & $-0.041^{* *}$ & 0.051 & -0.048 \\
& $(\mathrm{~N}=925)$ & $(1.85)$ & $(-1.82)$ & $(1.45)$ & $(-0.97)$ \\
& Incentive=0 & 0.326 & -0.019 & 0.039 & -0.033 \\
& $(\mathrm{~N}=2,979)$ & $(1.17)$ & $(-1.07)$ & $(1.27)$ & $(-0.74)$ \\
& Difference & 0.183 & -0.022 & 0.012 & -0.015 \\
& & $(0.58)$ & $(-0.83)$ & $(0.38)$ & $(-0.26)$ \\
\hline
\end{tabular}

